\title{
Synthesis and Characterization of Poly (lactic acid-b- E-caprolactone) Block Copolymers
}

\author{
Serhat ÖZTÜRK ${ }^{1}$, İsmail ÇAKMAK ${ }^{1}$, Ahmet Turan TEKEŞ ${ }^{1}$, Ümit YILDIKO ${ }^{2}$
}

\begin{abstract}
In this study, poly (lactic acid-b- $\varepsilon$-caprolactone) was synthesized with the ring opening polymerization of $\varepsilon$-caprolactone using of the poly lactic acid with the presence of DBTDL catalyst. In order to achieve that, poly lactic acid was synthesized by the condensation from the polymerization of the lactic acid with the $\mathrm{SnCI}_{2}$ catalyst. Poly (lactic acid-b-e-caprolactone) block copolymer was synthesized from the poly lactic acid (PLA) by changing some polymerization parameters such as polymer and monomer amounts and polymerization time. Block copolymers were characterized by using ${ }^{1} \mathrm{H}-\mathrm{NMR},{ }^{13} \mathrm{C}-\mathrm{NMR}, \mathrm{FT}-\mathrm{IR}, \mathrm{DSC}$ and GPC chromatography methods.
\end{abstract}

Key Words: Condensation polymerization, ring opening polymerization, poly lactic acid, block copolymer

\footnotetext{
'Terhat ÖZTÜRK (Orcid ID: 0000-0003-3865-5806, İsmail ÇAKMAK (Orcid ID: 0000-0002-3191-7570), Ahmet Turan TEKEŞ (Orcid ID: 0000-0002-9942-7367), Faculty of Arts and Sciences. Department of Chemistry, Kafkas University, Kars, Turkey.

${ }^{2}$ Ümit YILDIKO (Orcid ID: 0000-0001-8627-9038), Architecture and Engineering Faculty, Department of Bioengineering, Kafkas University, Kars, Turkey

* Sorumlu Yazar/Corresponding Author: Ümit YILDIKO, e-mail: yildiko1 @ gmail.com

* Bu çalışma Serhat ÖZTÜRK'ün Yüksek Lisans tezinden alınmıştır.
} 


\section{INTRODUCTION}

Poly (lactic acid) (PLA) is a polymer that is incorporated into the group of aliphatic polyesters whose repeating units consist of lactic acid(Jin, Hu, and Park 2019; Basu et al. 2016; Nofar et al. 2019; Saeidlou et al. 2012; Sonchaeng et al. 2018). One of the most important characteristics is that it is a biodegradable(Jin, Hu, and Park 2019; Wu et al. 2019; Nofar et al. 2019) and compostable(Kalita et al. 2019) thermoplastic polymer(Liu et al. 2019) produced from starch rich vegetable sources such as corn, sugarcane and wheat. With the increasing sensitivity of humans to the environment and the discovery of the new properties of the PLA, research on PLA has accelerated and provided more economic synthesis paths for high molecular weight PLA production. Thus, the use of poly (lactic acid) has started to expand and has started to spread to a wide range from packaging industry to general consumer products(Nofar et al. 2019; Gan and Chow 2018).

The lactide monomer forming the polylactic acid can be produced by carbohydrate fermentation or chemical synthesis. The PLA polymer can be synthesized in methods such as azeotropic dehydrative condensation, direct condensation or lactide polymerization. However, the synthesis, which is frequently used in industry, is carried out by ring opening polymerization mechanism. By this method, high molecular weight PLA is obtained. In recent years new synthesis mechanisms have also been found in commercial life(CastroAguirre et al. 2016).

$\varepsilon$-caprolactone(Moraczewski 2014) can also be copolymerized with a large number of different monomers (ethylene oxide, styrene, methyl methacrylate, vinyl acetate, etc.)(Sisson, Ekinci, and Lendlein 2013; Sinha et al. 2004). In addition, PCL tends to form a mixture compatible with many different polymers(Guindani et al. 2019; Jang et al. 2018;
Wang et al. 2018). Thanks to these properties, PCL can work alone or in combination with other polymers in tissue engineering studies(Dalgic et al. 2019; Pedram Rad, Mokhtari, and Abbasi 2018).

Poly $(\varepsilon)$-caprolactone was synthesized by ring-opening polymerization using hydrophobised silylated starch precursor. Poly (ع) -caprolactone side chains consist of 40-45 monomer units and are a function of reagent uptake. Poly $(\varepsilon)$-caprolactone copolymer was synthesized by $(\varepsilon)$-caprolactone ring-opening polymerization in tin octoate medium(Sinha et al. 2004; Wang et al. 2018).

Depending on the chemical components and molecular structures, block copolymers reveal interesting physicochemical properties which cause many applications(Cama et al. 2017). They can be used as stabilizers, emulsifiers, dipersing agents, elastomeric materials and surfactants, as well as in drug release(de Cassan et al. 2018), cosmetics, and many other industrial applications.

Murphy et al. prepared new materials by blending poly ( $\varepsilon$-caprolactone) (PCL) and poly (lactic acid) (PLA) mixtures(Murphy et al. 2017). In this respect, synthesis with good properties as block copolymers is required..

In this study, poly (lactic acid-b- $\varepsilon^{-}$ caprolactone) was synthesized by ring opening polymerization of DBTDL catalyzed $\varepsilon^{-}$ caprolactone using poly lactic acid. Poly (lactic acid-b- $\varepsilon$-caprolactone) block copolymer was synthesized by varying various parameters (amount of polymer, amount of monomer and polymerization time)

\section{MATERIALS AND METHODS Materials}

Lactic acid (80\% Sigma-Aldrich product), Tin (II) chloride $(\mathrm{SnCl} 2)$ (Sigma-Aldrich product), P-toluene sulfonic acid (Sigma-Aldrich product), Diethyl ether (Sigma-Aldrich product), 
$\varepsilon^{-}$caprolactone (Sigma-Aldrich product), Toluene (Sigma-Aldrich product) and used as received. Silicone oil is a product of SigmaAldrich which is used to heat the material to a certain temperature with the heater in the beaker. Methanol (Technical product) was used as received. Chloroform was EMBOY product. Dibutyl tin was used as received dilaurat lens product.

\section{Methods}

\section{Synthesis of Poly (lactic acid) Polymer by Condensation Polymerization}

In the study, $50 \mathrm{~g}$ of $80 \%$ Lactic acid, $1.2 \mathrm{~g}$ of SnCI2 and $1 \mathrm{~g}$ of p-toluene sulfonic acid were weighed and placed in a glass flask. When the temperature of a liquid filled beaker was reached to a temperature above $140{ }^{\circ} \mathrm{C}$ with the heat exchanger, these chemicals were subjected to polymerization with the back cooling and vacuum assembly.

The silicone oil bath was held at $140^{\circ} \mathrm{C}$ for about 24 hours (the oil filled beaker was surrounded by isocam to prevent temperature loss). The polymer was removed from the flask, added chloroform and stirred for 2 hours with the aid of a magnet. A portion of the solvent in the flask was evaporated in a rotary evaporator and precipitated with diethyl ether. The polymer was kept in the vacuum oven at $30^{\circ} \mathrm{C}$ for 1 week. $25.73 \mathrm{~g}$ of poly (lactic acid) were obtained in $49.3 \%$ yield (Figure 1).

Synthesis of Poly (lactic acid- b- $\varepsilon$ caprolactone) Block Copolymers

A quantity of poly (lactic acid) polymer, $\varepsilon-$ caprolactone momomer, toluene and DBTDL (Dibutyl tin dilaurate) (required catalyst to provide ring opening) was put into a test tube and the tube was sealed. The reaction temperature was adjusted to $95^{\circ} \mathrm{C}$ and polymerization was carried out. After the polymerization was completed, the polymer was precipitated in methanol and the polymer was withdrawn by precipitation with methanol. To thoroughly remove the methanol, the polymer was allowed to dry well at $30^{\circ} \mathrm{C}$ in a vacuum oven. The reaction was repeated by changing the test conditions (amount of polymer, amount of monomer and hour)(Figure 2)<smiles>CC(O)C(=O)O</smiles>

Lactic acid

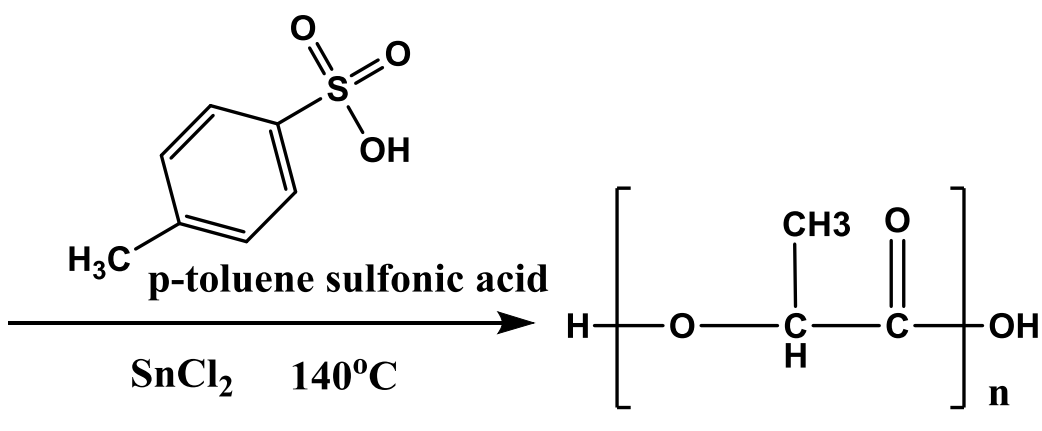

polylactic acid

Figure 1. Polymerization of lactic acid 
<smiles>CC(C)OC(C)C(=O)O</smiles>

polylactic acid

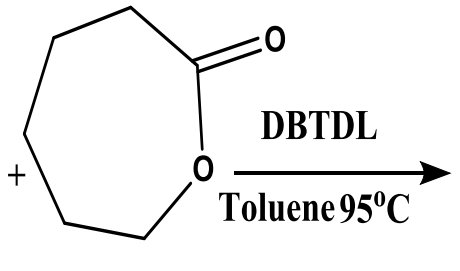

$\varepsilon$-caprolactone<smiles>CC(C)OC(=O)C(C)OC(=O)C(C)OC(C)C</smiles>

Poly (lactic acid-b-e-caprolactone)

Figure 2. Synthesis reaction of poly (lactic acid-b-e-caprolactone) Block Copolymer

\section{RESULT AND DISCUSSION}

\section{Condensation Polymerization of Lactic Acid}

Synthesis of Poly (lactic acid) Polymer by Condensation Polymerization

In condensation polymerization, functional monomer groups have proven their success(Mallakpour and Hatami 2017). Polymers with certain molecular weight and low polydispersity indices (PDI) can be given condensation of a wide variety of monomers under mild conditions(Lynd, Meuler, and Hillmyer 2008). In this study, two sets of polymerization of polylactic acid were introduced and the polymerization of $\varepsilon$-CL was carried out in two sets. The silicone oil bath was carried out at $140^{\circ} \mathrm{C}$ as described in the experiment. Synthesis-related reaction conditions and GPC results are given in Table 1.
The amount of PLA and $\varepsilon$-CL were fixed and the polymerization time was changed. When the amount of polymer (PLA) is increased and the amount of monomer ( $\varepsilon-C L)$ is kept constant, the amount of polymer (PLA) is kept constant and the amount of monomer $(\varepsilon-\mathrm{CL})$ is increased or the amount of polymer (PLA) and monomer ( $\varepsilon$ CL) are kept constant. It was. The heterogeneity index of the obtained block copolymers was found to be between 1.55-3.42. The synthesized PLA was found to be 2.27. The molecular weight of PLA was $1448.9 \mathrm{~g} / \mathrm{mol}$ and the block copolymer of 1728.9-7471.0 g / mol. The fact that the molecular weight of the obtained block copolymers is higher than the PLA used as initiators indicates the synthesis of block copolymers.

Table 1. Reaction conditions and GPC results of synthesis of polylactic acid

\begin{tabular}{cccccc}
\hline $\mathbf{8 0} \%$ Lactic acid $(\mathrm{g})$ & $\mathbf{S n C I}_{\mathbf{2}} \mathbf{( g )}$ & $\mathbf{p}$-toluene sulfonic acid (g) Yied (\%) & $\overline{\mathbf{M}}_{\mathrm{n}}$ & $\left(\mathbf{g ~ m o l}^{-\mathbf{1}}\right)$ & $\mathbf{M w} / \overline{\mathbf{M}}_{\mathrm{n}}$ \\
\hline 50 & 1.2 & 1 & 49.3 & 1448.8 & 2.27 \\
\hline
\end{tabular}

FT-IR (KBr): $3647.05-3511.33 \mathrm{~cm}-1 \mathrm{OH}$ strain vibration, 2998.79-2879.55 cm-1 Aliphatic C-H strain vibration, $1760.99 \mathrm{~cm}-1 \mathrm{C}=\mathrm{O}$ tensile vibration, $1292.30-1212.58 \mathrm{~cm}-1$ COO strain vibration peaks are observed. PLA FT-IR graph is given in figure 3 . 


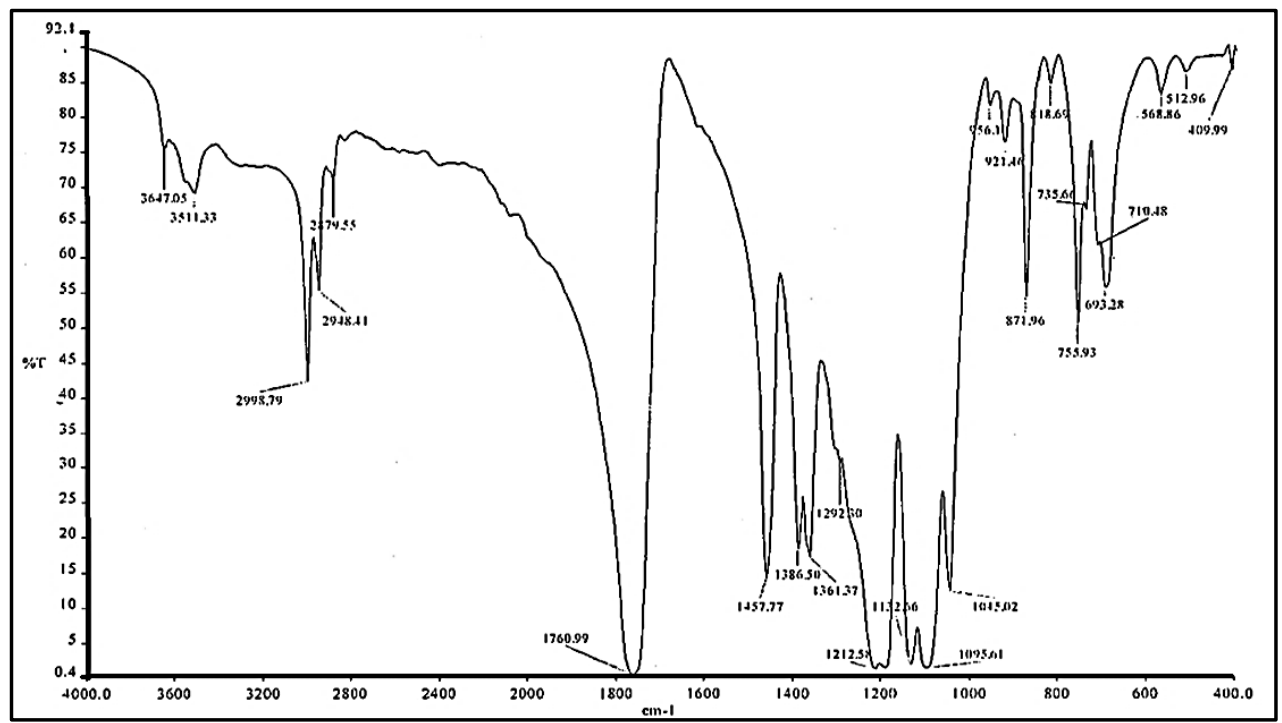

Figure 3. FT-IR spectrum of poly lactic acid (PLA)

${ }^{1} \mathbf{H}-\mathbf{N M R}$ ( $\mathrm{CDCI}_{3}$ ): The protons of the $-\mathrm{CH}_{3}$ group at $1.5 \mathrm{ppm}$, the protons of the proton groups at 4.3-4.4 ppm, and the proton of the $\mathrm{CH}$ group at 5.1-5.3 $\mathrm{ppm}$ are seen. PLA ${ }^{1} \mathrm{H}-\mathrm{NMR}$ graph is given in figure 4 .

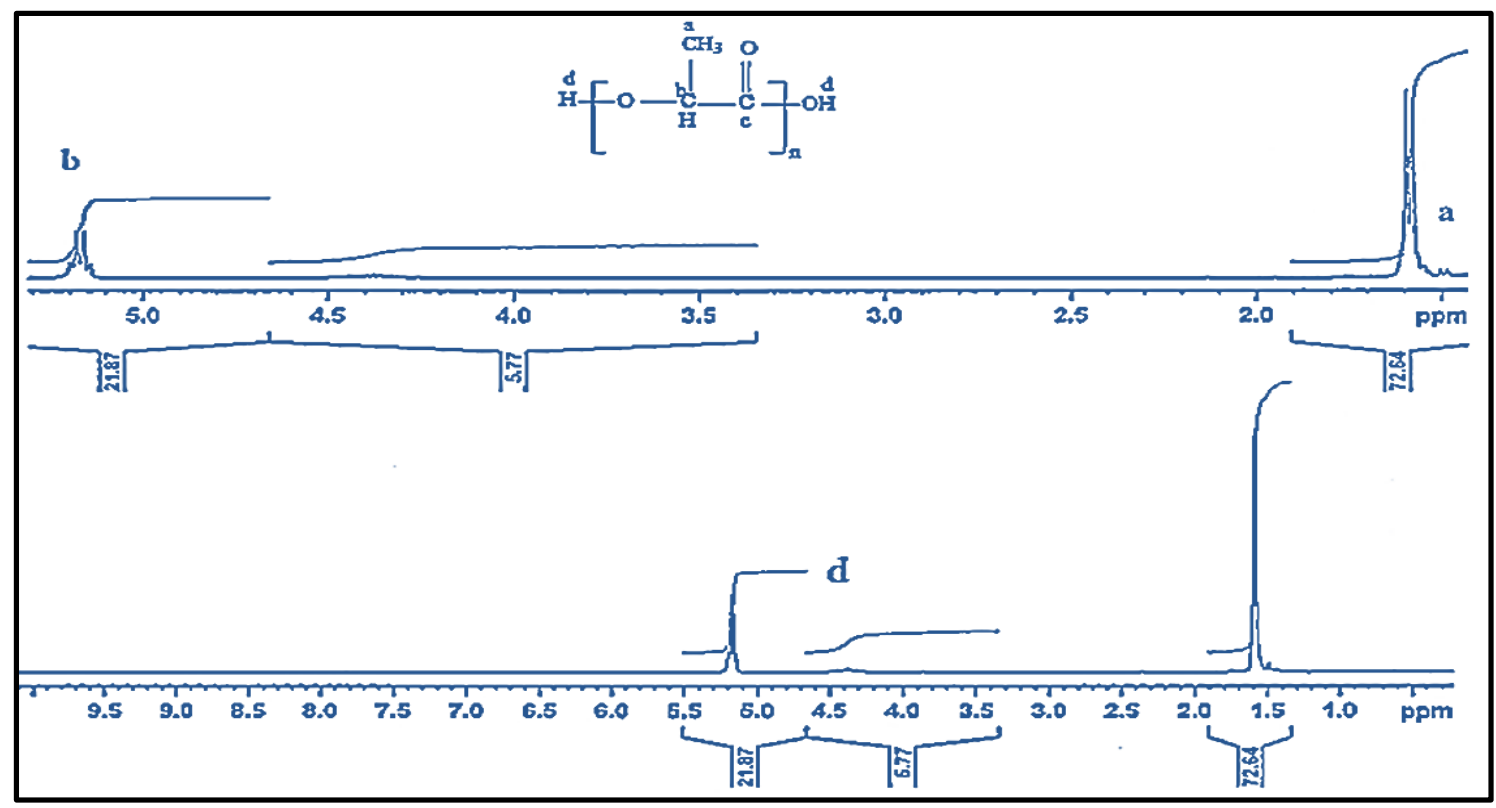

Figure 4. ${ }^{1} \mathrm{H}-\mathrm{NMR}$ spectrum of poly lactic acid (PLA)

${ }^{13}$ C-NMR (CDCl3): At 16.62-16.66 ppm, the carbon atom of the -- $\mathrm{CH} 3$ group, the carbon atom of the "CH" group at $69.01 \mathrm{ppm}$, the peaks of the carbon atom of the " $\mathrm{C}=\mathrm{O}$ " group at 169.60 ppm. PLA ${ }^{13} \mathrm{C}-\mathrm{NMR}$ graph is given in figure 5 . 


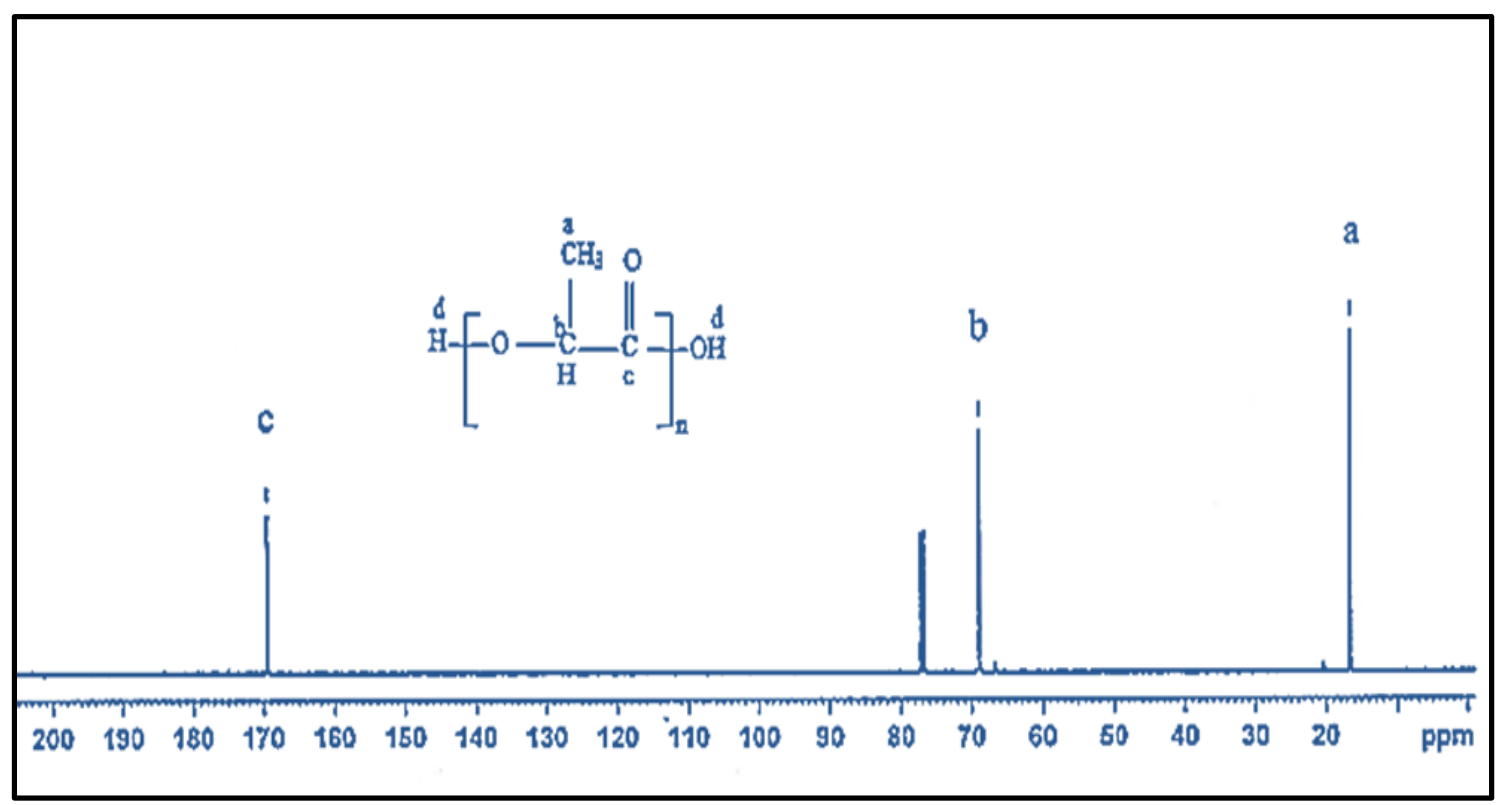

Figure 5. ${ }^{13} \mathrm{C}-\mathrm{NMR}$ spectrum of poly lactic acid (PLA)

The reaction conditions and GPC results of the synthesis of poly (lactic acid- b- $\varepsilon^{-}$ caprolactone) block copolymers are given in
Table 2. Poly (lactic acid-b-e-caprolactone) Graphical drawings were drawn with the OriginPro 9 program.

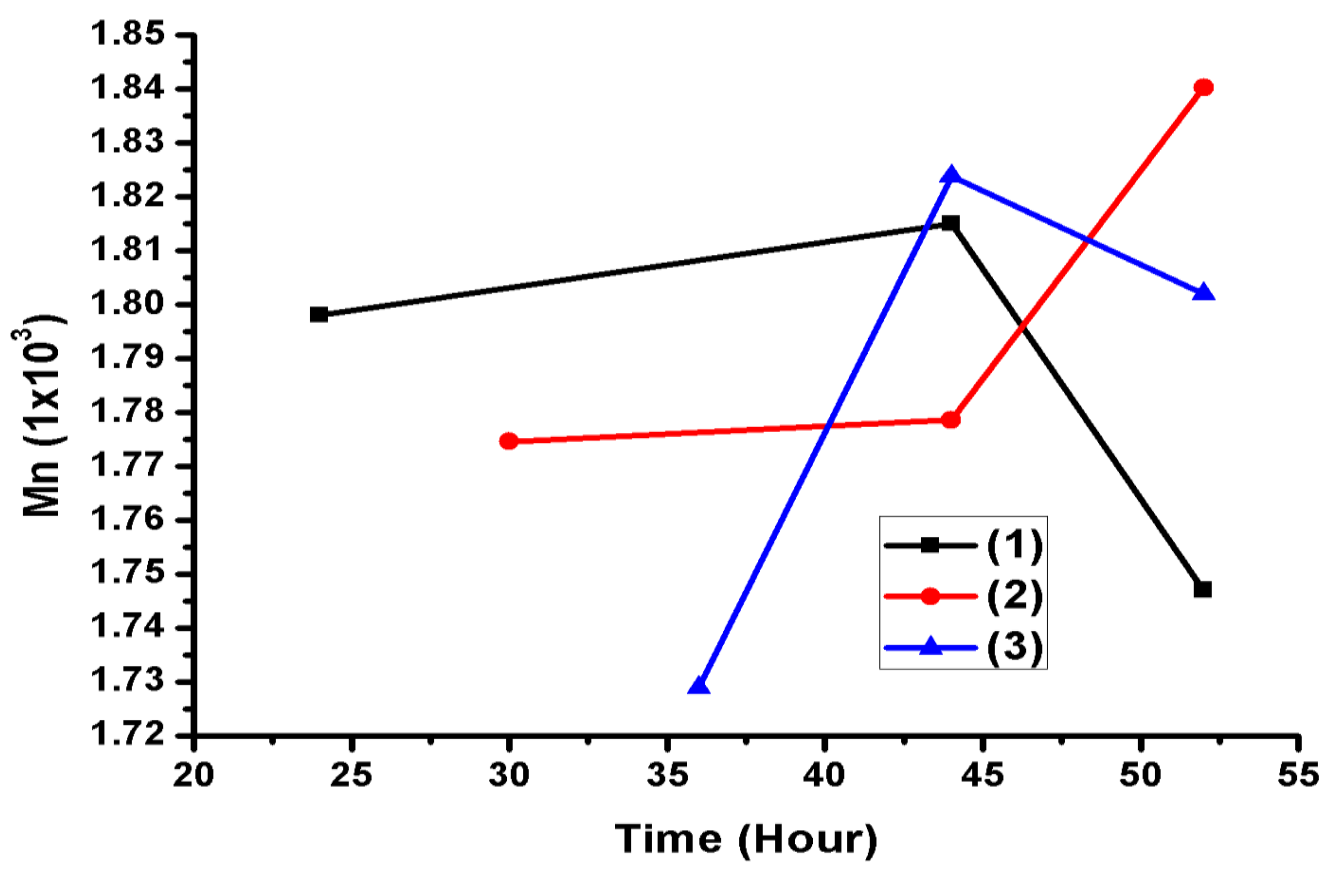

Figure 6. Molecular weight graph of poly (lactic acid-b-e-caprolactone) reaction against time 
Table 2. Poly (lactic acid-b-e-caprolactone) Reaction conditions and GPC results of Block Copolymer synthesis

\begin{tabular}{cccccccc}
\hline Exp. No. & Exp. Code & PLA $(\mathbf{g})$ & $\mathbf{E - C L}(\mathbf{g})$ & Test time $(\mathbf{h})$ & $\overline{\mathbf{M}}_{\mathrm{n}}\left(\mathbf{g ~ m o l}^{\mathbf{1}}\right)$ & $\mathbf{M w}_{\mathbf{n}} \overline{\mathrm{M}}_{\mathrm{n}}$ & Yield (\%) \\
\hline 1 & $\mathrm{~A}_{1}$ & 0.3038 & 1.0150 & 44 & 1815.7 & 1.67 & 52 \\
2 & $\mathrm{~B}_{1}$ & 0.5018 & 1.0066 & 52 & 7471.0 & 2.38 & 54 \\
3 & $\mathrm{C}_{1}$ & 0.2540 & 1.0235 & 24 & 1798.4 & 1.99 & 67 \\
4 & $\mathrm{~A}_{2}$ & 0.5006 & 1.2000 & 44 & 1774.6 & 1.94 & 56 \\
5 & $\mathrm{~B}_{2}$ & 0.5025 & 1.2875 & 52 & 1840.3 & 1.88 & 61 \\
6 & $\mathrm{C}_{2}$ & 0.2505 & 1.0326 & 30 & 1774.6 & 1.72 & 73 \\
7 & $\mathrm{~A}_{3}$ & 0.6023 & 1.0000 & 44 & 1823.9 & 3.42 & 59 \\
8 & $\mathrm{~B}_{3}$ & 0.5014 & 1.5300 & 52 & 1802.0 & 1.92 & 70 \\
9 & $\mathrm{C}_{3}$ & 0.2502 & 1.0841 & 36 & 1728.9 & 1.70 & 76 \\
10 & $\mathrm{~B}_{4}$ & 0.5021 & 2.7686 & 52 & 1753.1 & 1.55 & 45 \\
\hline
\end{tabular}

Temperature $=95^{\circ} \mathrm{C}$; Toluene $=2 \mathrm{ml} ;$ DBTDL; 1 drop; $*$ precipitator $($ methanol, $\mathrm{ml})$

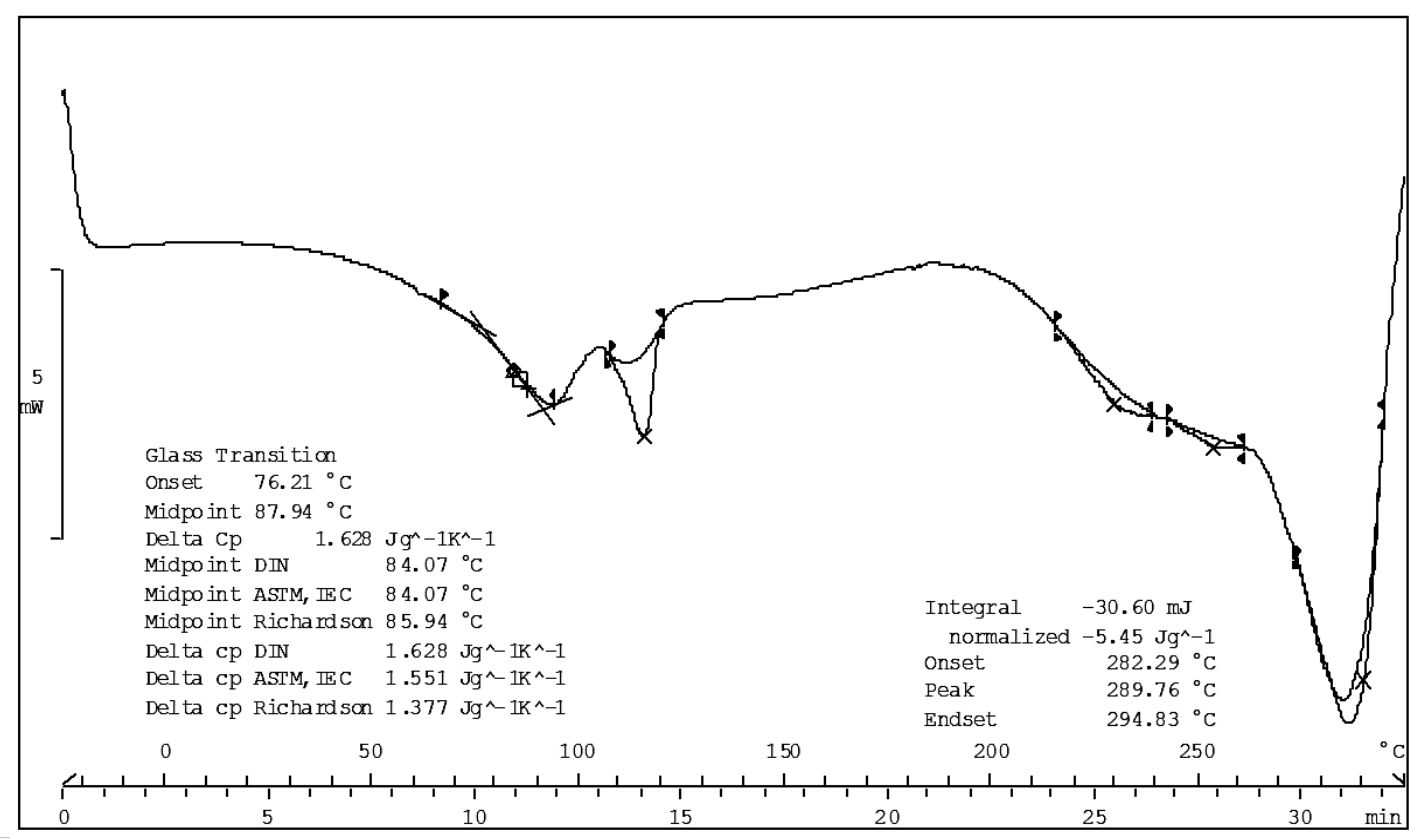

Figure 7. DSC diagram of poly lactic acid (PLA)

Differential scanning calorimetry based techniques are important when characterizing polymers(Drzeżdżon et al. 2019; Fitzharris, Rosen, and Shofner 2019). In the DSC spectrum of poly (lactic acid), $\mathrm{Tg}$ (glass transition temperature) at $76.21^{\circ} \mathrm{C}$ and $\mathrm{Td}$ (melting temperature) at $115.65^{\circ} \mathrm{C}$ were seen in Figure 7.

The DSC spectrum of poly (lactic acid-b-ecaprolactone) showed $\mathrm{Tg}$ (glass transition temperature) at $29.04^{\circ} \mathrm{C}$ and $\mathrm{Td}$ (melting temperature) at $52.16^{\circ} \mathrm{C}$ in Figure 8. Differential scanning calorimetry (DSC) and glass transition temperature $(\mathrm{Tg})$ and melting temperature $(\mathrm{Tm})$ of the obtained polymers were determined. The addition of poly (lactic acid) g e $\varepsilon$-CL reduced the $\mathrm{Tg}$ and $\mathrm{Td}$ values of the block copolymer of poly (lactic acid). The ratio of the glass transition temperature ( $\mathrm{Tg}$ ) and melting temperature $(\mathrm{Tm})$ of the obtained block copolymer to a value between the glass transition temperature ( $\mathrm{Tg}$ ) and the melting temperature (Tm) of the poly (lactic acid) and $\varepsilon^{-}$ CL were determined. it is confirmed. 


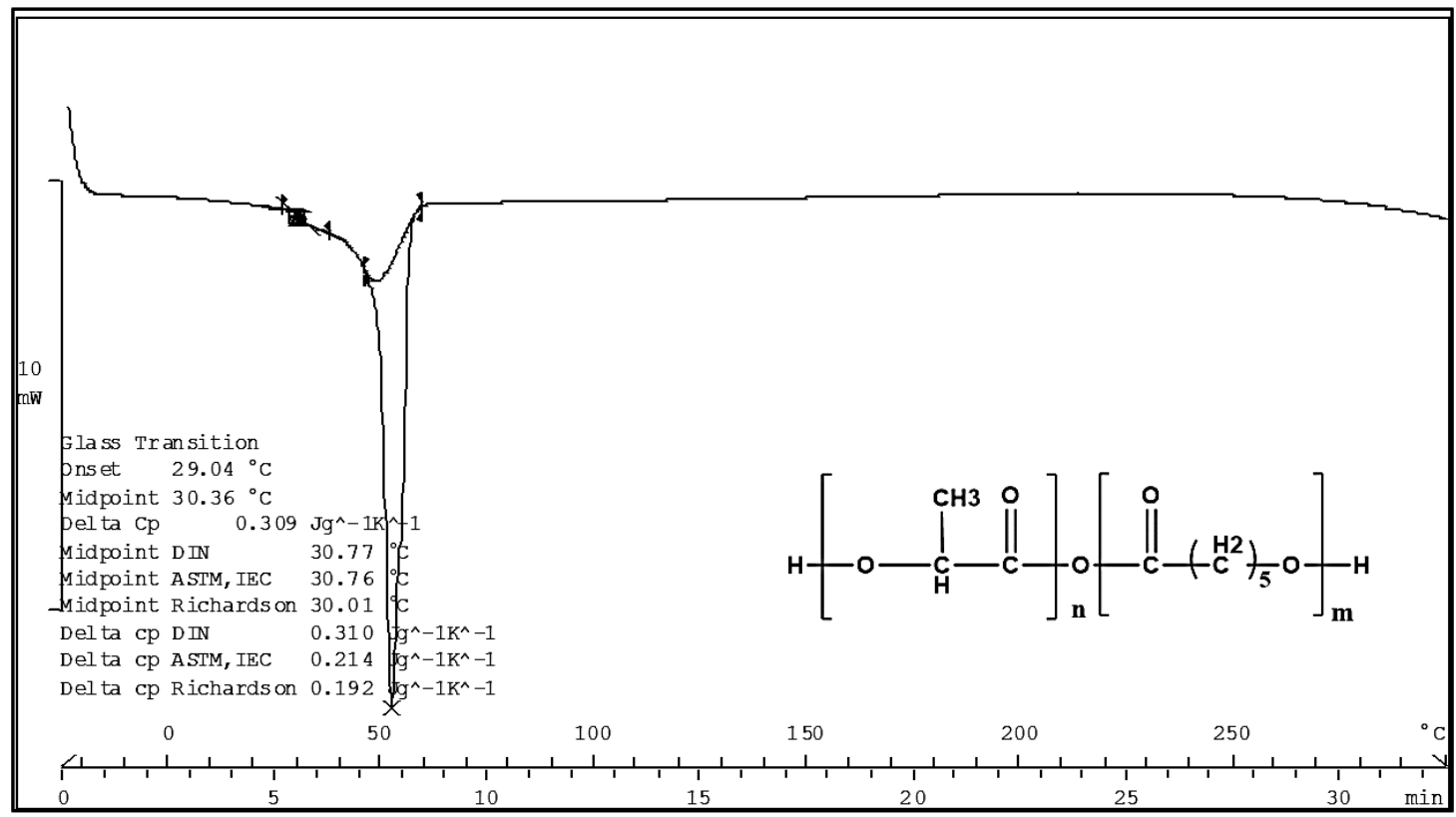

Figure 8. DSC spectrum of poly (lactic acid- b- $\varepsilon$-caprolactone) block copolymer

FT-IR (KBr): $3630.25-3551.82 \mathrm{~cm}^{-1} \mathrm{OH}$ tensile vibration, $2946.97-2867.02 \mathrm{~cm}^{-1}$ Aliphatic C-H tensile vibration, $1725.52 \mathrm{~cm}^{-1} \mathrm{C}$ $=\mathrm{O}$ stress vibration, $1243.62-1295.77 \mathrm{~cm}^{-1}$ COO stress vibration peaks are observed.
$3439.03 \mathrm{~cm}-1 \mathrm{C}=\mathrm{O}$ overton band $(2 \times 1725.52)$. The FT-IR graph of the poly (lactic acid-b- $\varepsilon^{-}$ caprolactone) block copolymer is given in figure 9.

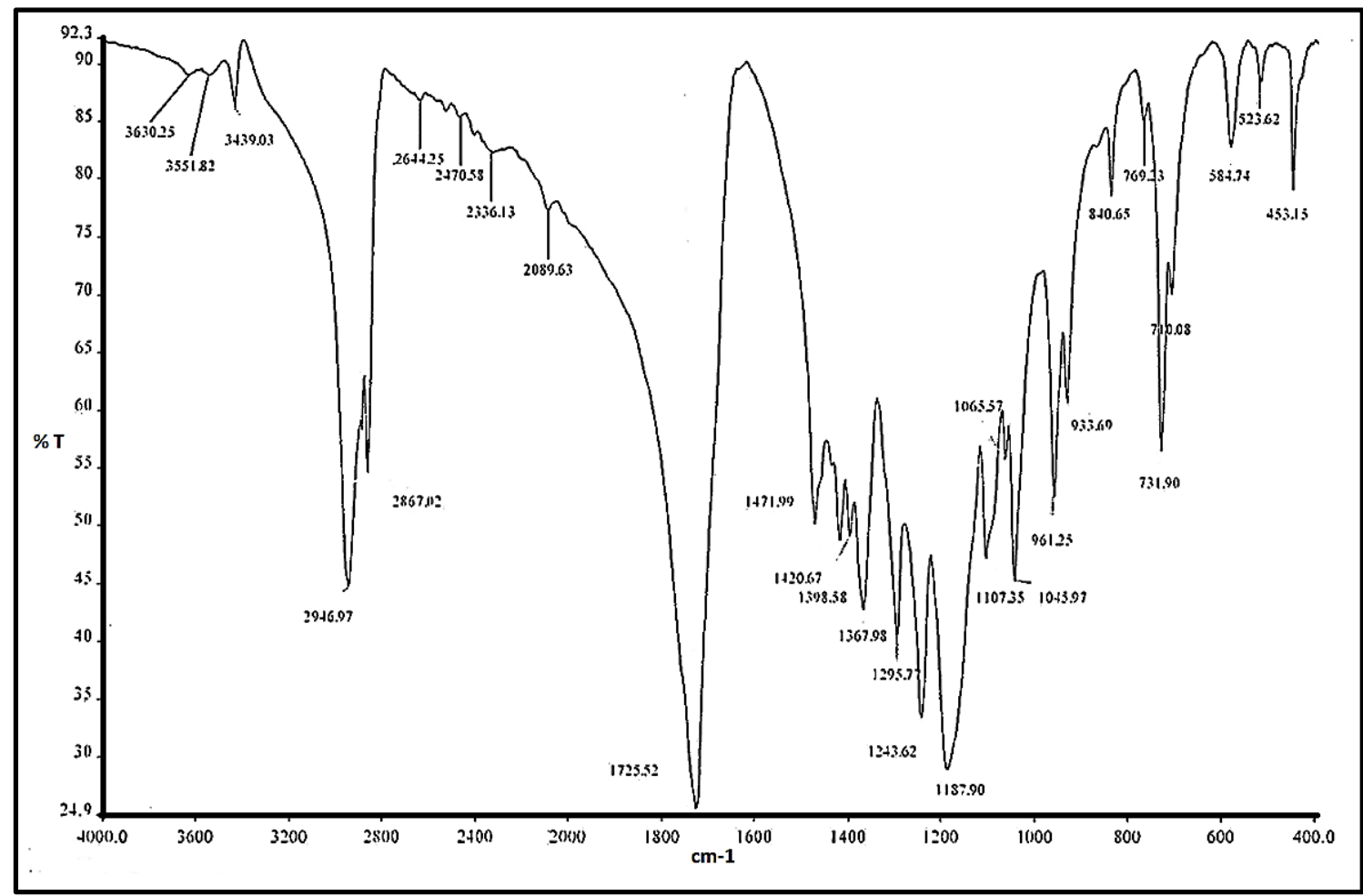

Figure 9. FT-IR spectrum of poly (lactic acid- b- $\varepsilon$-caprolactone) block copolymer (B4) 
${ }^{1}$ H-NMR (CDCl 3): protons of (a) at 5.1446$5.1619 \mathrm{ppm}$, protons of (b) at 4.0357-4.0655 ppm, protons of (i) at 2.2774-2.3139 ppm, 1.5588-1.6323 ppm The protons of $(\mathrm{k})$ show protons of (c) at 1.3590-1.4090 ppm. The ${ }^{1} \mathrm{H}-$ NMR graph of the poly (lactic acid-b- $\varepsilon$ caprolactone) block copolymer is given in figure 10.

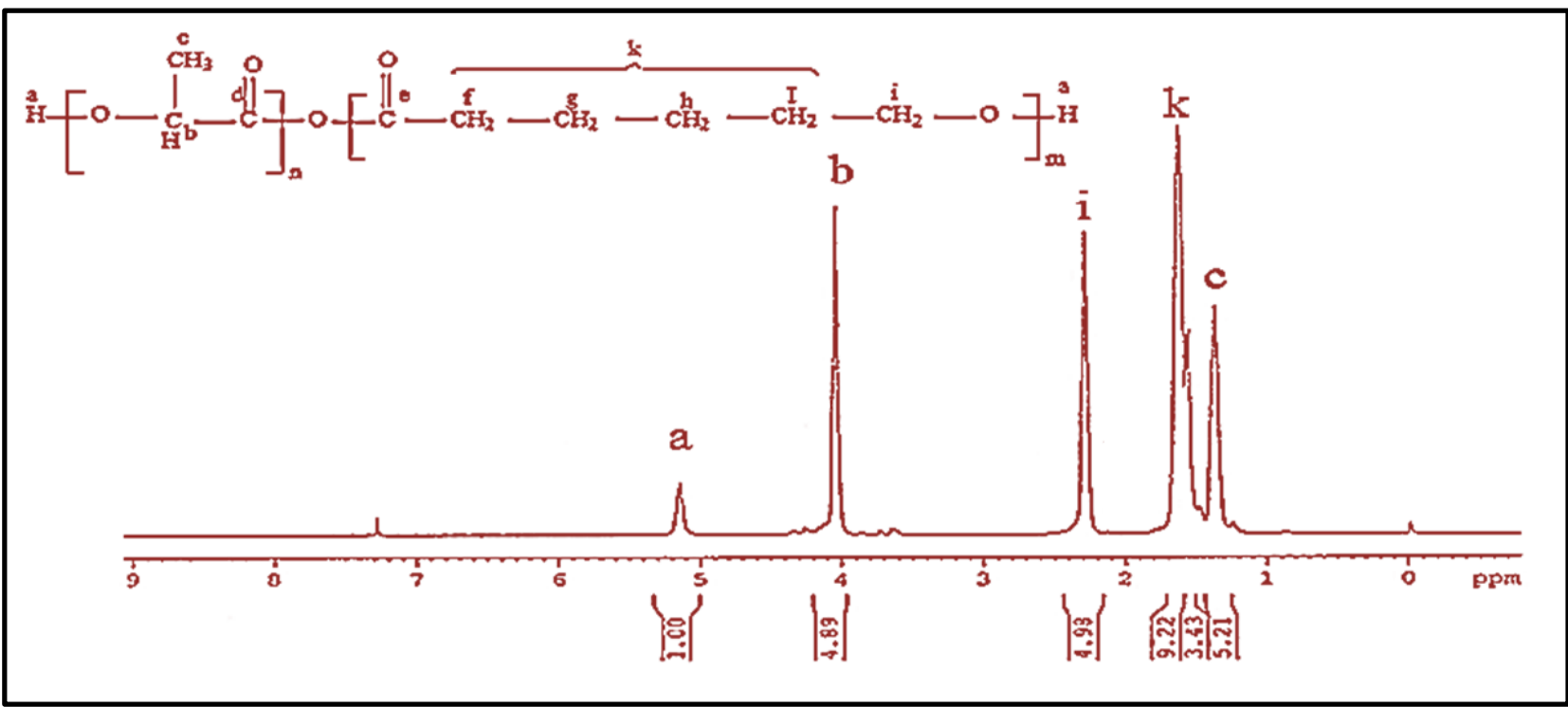

Figure 10. ${ }^{1} \mathrm{H}-\mathrm{NMR}$ spectrum of poly (lactic acid-b- $\varepsilon$-caprolactone) block copolymer

${ }^{13}$ C-NMR (CDCl 3, $\left.\boldsymbol{\delta}, \mathbf{p p m}\right): 173.52$ (carbon of e '), 169.56 (carbon of d), 68.98 (carbon of b), 64.11 (carbon of i), 34.09 (carbon of $\mathrm{f}$ ) , 28.32 (carbon of g), 25.50 (carbon of I), 24.55 (carbon of h), 16.61 (carbon of c). The ${ }^{13} \mathrm{C}-\mathrm{NMR}$ graph of the poly (lactic acid-b- $\varepsilon$-caprolactone) block copolymer is given in figure 11 .<smiles>CCOCCCCCCCC(=O)OCC(C)C(=O)OCC</smiles>

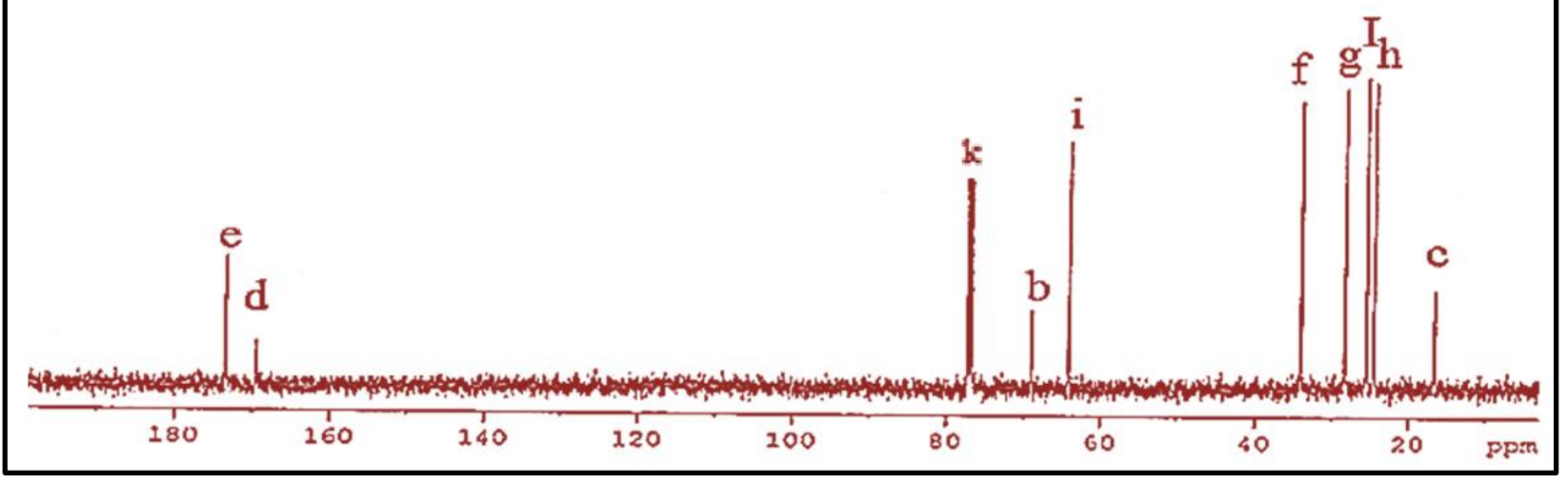

Figure 11. ${ }^{13} \mathrm{C}$-NMR spectrum of poly (lactic acid- b- $\varepsilon$-caprolactone) block copolymer 


\section{CONCLUSION}

In this study, the synthesis of poly (lactic acid-b- $\varepsilon$-caprolactone) block copolymers was carried out by ring opening polymerization of $\varepsilon$ caprolactone of poly lactic acid. Poly lactic acid (PLA) was synthesized by condensation polymerization of lactic acid. Poly (lactic acid-be-caprolactone) block copolymer was synthesized by changing various parameters (amount of polymer, amount of monomer and polymerization time). .

The use of biomaterials of bio-origin, biocompatible, and biocompatible, plays an active role in many areas of the world of technology. Particularly, poly (lactic acid) (PLA), which is in the part of biopolymers, has different degradation processes and it increases the usage areas of this polymer, block copolymers and composites. With the new block properties of poly (lactic acid- b- $\varepsilon$-caprolactone) block copolymers, medical, environmental, packaging and textiles will increase their importance in many areas.

\section{REFERENCES}

Arijit B, Kunduru KR, Doppalapudi S, Domb AJ, and Khan W, 2016. 'Poly(lactic acid) based hydrogels', Advanced Drug Delivery Reviews, 107: 192-205.

Cama G, Mogosanu DE, Houben A, and Dubruel P, 2017. '3 - Synthetic biodegradable medical polyesters: Poly- $\varepsilon$-caprolactone.' in Xiang Zhang (ed.), Science and Principles of Biodegradable and Bioresorbable Medical Polymers (Woodhead Publishing).

Camila G, Dozoretz P, Pedro H, Araújo H, Sandra R, Ferreira S, and Oliveira D 2019. 'N-acetylcysteine side-chain functionalization of poly(globalide-co- $\varepsilon^{-}$ caprolactone) through thiol-ene reaction', Materials Science and Engineering: C, 94: 477-83.
Castro-Aguirre E, Iñiguez-Franco F, Samsudin H, Fang X, and Auras R, 2016. 'Poly(lactic acid)-Mass production, processing, industrial applications, and end of life', Advanced Drug Delivery Reviews, 107: 333-66.

Dalgic AD, Deniz A, Karatas A Tezcaner A, and Keskin D, 2019. 'Diatom shell incorporated PHBV/PCL-pullulan coelectrospun scaffold for bone tissue engineering', Materials Science and Engineering: C, 100: 735-46.

Dominik C, Sydow S, Schmidt N, Behrens P, Roger Y, Hoffmann A, Hoheisel AL, Glasmacher B, Hänsch R, and Menzel H, 2018. 'Attachment of nanoparticulate drugrelease systems on poly( $\varepsilon$-caprolactone) nanofibers via a graftpolymer as interlayer', Colloids and Surfaces B: Biointerfaces, 163: 309-20.

Emily RF, Rosen WD, and Shofner ML, 2019. 'Fast scanning calorimetry for semicrystalline polymers in fused deposition modeling', Polymer, 166: 196205.

Fan-Long J, Rong-Rong H, and Park SJ, 2019. 'Improvement of thermal behaviors of biodegradable poly(lactic acid) polymer: A review', Composites Part B: Engineering, 164: 287-96.

Joanna D, Jacewicz D, Sielicka A, and Chmurzyński L, 2019. 'Characterization of polymers based on differential scanning calorimetry based techniques', TrAC Trends in Analytical Chemistry, 110: 5156.

Ivy G, and Chow WS, 2018. 'Antimicrobial poly(lactic acid)/cellulose bionanocomposite for food packaging application: A review', Food Packaging and Shelf Life, 17: 150-61.

Krzysztof M, 2014. 'Characterization of multiinjected poly( $\varepsilon$-caprolactone)', Polymer Testing, 33: 116-20. 
Kumar KN, Nagar MK, Mudenur C, Kalamdhad A, and Katiyar V, 2019. 'Biodegradation of modified Poly(lactic acid) based biocomposite films under thermophilic composting conditions', Polymer Testing.

Lynd, NA, Meuler AJ, and Hillmyer MA, 2008. 'Polydispersity and block copolymer selfassembly', Progress in Polymer Science, 33: 875-93.

Murphy SH, Marsh JJ, Kelly CA, Leeke GA, and Jenkins MJ, 2017. 'CO2 assisted blending of poly(lactic acid) and poly $(\varepsilon-$ caprolactone)', European Polymer Journal, 88: 34-43.

Ningjing W, Guoliang F, Yang Y, Xia M, Yun H, and Wang Q, 2019. 'Fire safety enhancement of a highly efficient flame retardant poly(phenylphosphoryl phenylenediamine) in biodegradable poly(lactic acid)', Journal of Hazardous Materials, 363: 1-9.

Nofar M, Sacligil D, Carreau PJ, Kamal MR, and Heuzey MC, 2019. 'Poly (lactic acid) blends: Processing, properties and applications', International Journal of Biological Macromolecules, 125: 307-60.

Rad P, Mokhtari Z J, and Abbasi M, 2018. 'Fabrication and characterization of PCL/zein/gum arabic electrospun nanocomposite scaffold for skin tissue engineering', Materials Science and Engineering: C, 93: 356-66.

Sajjad S, Huneault MA., Li H, and Park CB, 2012. 'Poly(lactic acid) crystallization', Progress in Polymer Science, 37: 1657-77.

Shadpour M, and Hatami M, 2017. 'Condensation polymer/layered double hydroxide NCs: Preparation, characterization, and utilizations', European Polymer Journal, 90: 273-300.
Sinha VR, Bansal K, Kaushik R, Kumria R, and

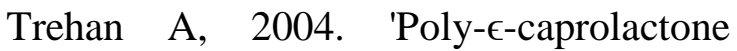
microspheres and nanospheres: an overview', International Journal of Pharmaceutics, 278: 1-23.

Sisson, Adam L., Duygu Ekinci, and Andreas Lendlein. 2013. 'The contemporary role of $\varepsilon$-caprolactone chemistry to create advanced polymer architectures', Polymer, 54: 4333-50.

Su-Hee J,Dae-Hoon K, Park DH, Kim OY, and Hwang SH, 2018. 'Construction of sustainable polyurethane-based gel-coats containing poly( $\varepsilon$-caprolactone)-grafted lignin and their coating performance', Progress in Organic Coatings, 120: 234-39. Uruchaya S, Fabiola IF, Auras R, Selke S, Rubino M, and Lim LT, 2018. 'Poly(lactic acid) mass transfer properties', Progress in Polymer Science, 86: 85-121.

Xiansong W, Liu S, Wang Q, Li J, and Wang. G, 2018. 'Synthesis and characterization of poly(ethylene 2,5-furandicarboxylate-co- $\varepsilon$ caprolactone) copolyesters', European Polymer Journal, 109: 191-97.

Xiang L, Zhou L, Heng P, Xiao J, Lv J, Zhang Q, Hickey ME, Qin T, and Jinyi W. 2019. 'Lecithin doped electrospun poly(lactic acid)-thermoplastic polyurethane fibers for hepatocyte viability improvement', Colloids and Surfaces B: Biointerfaces, 175: 264-71. 